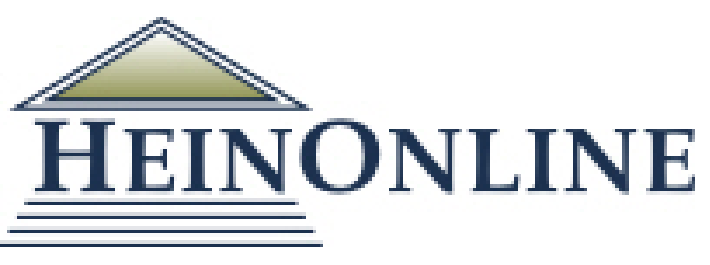

Content downloaded/printed from

HeinOnline

Mon Oct 7 07:37:40 2019

Citations:

Bluebook 20th ed.

Nicholas Wasonga Orago, The Place of the Minimum Core Approach in the Realisation of the Entrenched Socio-Economic Rights in the 2010 Kenyan Constitution, 59 J. Afr. L. 237 (2015).

ALWD 6th ed.

Nicholas Wasonga Orago, The Place of the Minimum Core Approach in the Realisation of the Entrenched Socio-Economic Rights in the 2010 Kenyan Constitution, 59 J. Afr. L. 237 (2015).

APA 6th ed.

Orago, N. (2015). The place of the minimum core approach in the realisation of the entrenched socio-economic rights in the 2010 kenyan constitution. Journal of African Law, 59(2), 237-270.

Chicago 7th ed.

Nicholas Wasonga Orago, "The Place of the Minimum Core Approach in the Realisation of the Entrenched Socio-Economic Rights in the 2010 Kenyan Constitution," Journal of African Law 59, no. 2 (October 2015): 237-270

McGill Guide 9th ed.

Nicholas Wasonga Orago, "The Place of the Minimum Core Approach in the Realisation of the Entrenched Socio-Economic Rights in the 2010 Kenyan Constitution" (2015) 59:2 J

Afr L 237.

MLA 8th ed.

Orago, Nicholas Wasonga. "The Place of the Minimum Core Approach in the Realisation of the Entrenched Socio-Economic Rights in the 2010 Kenyan Constitution." Journal of African Law, vol. 59, no. 2, October 2015, p. 237-270. HeinOnline.

OSCOLA 4th ed.

Nicholas Wasonga Orago, 'The Place of the Minimum Core Approach in the Realisation of the Entrenched Socio-Economic Rights in the 2010 Kenyan Constitution' (2015) $59 \mathrm{~J}$ Afr L 237

-- Your use of this HeinOnline PDF indicates your acceptance of HeinOnline's Terms and Conditions of the license agreement available at https://heinonline.org/HOL/License

-- The search text of this PDF is generated from uncorrected OCR text.

-- To obtain permission to use this article beyond the scope of your license, please use: Copyright Information

Use QR Code reader to send PDF to your smartphone or tablet device 


\title{
The Place of the "Minimum Core Approach" in the Realisation of the Entrenched Socio-Economic Rights in the 2010 Kenyan Constitution
}

\author{
Nicholas Wasonga Orago*
}

\begin{abstract}
The high levels of poverty, inequality and socio-economic marginalisation that bedevilled Kenya for generations led to a struggle for a new constitutional dispensation, which culminated in the promulgation of a new, egalitarian and transformative constitution in August 2010. This constitution entrenched justiciable socio-economic rights within an elaborate Bill of Rights. Though an important step in the process of the egalitarian transformation of the country, the challenge remains to transform these precepts into practice with their scrupulous implementation through legislative, policy and programmatic frameworks, as well as judicial decision-making. This article argues that, in order to achieve the intended egalitarian transformation, Kenya must adopt a strong interpretive approach, with sufficient foundational standards for the translation of these rights into tangible realities for Kenyans. Kenya must therefore explicitly adopt a minimum core approach for the realisation of these rights to transform them into practical realities for the poor, vulnerable and marginalised Kenyans.
\end{abstract}

\section{INTRODUCTION}

High levels of poverty, inequality and the socio-economic marginalization of the majority of the Kenyan people have been major challenges to the achievement of sustainable development in Kenya. The poverty level in Kenya is among the world's highest, with approximately $46-56$ per cent of the population living below the poverty line, ${ }^{1}$ showing no real improvement from the

* Lecturer, School of Law, University of Nairobi, Kenya.

1 Government of Kenya "Poverty reduction strategy paper. First medium term plan 20082012" (submitted to the International Monetary Fund) at ii, available at: <http://www. imf.org/external/pubs/ft/scr/2010/cr10224.pdfs (last accessed 8 June 2013). However, many commentators have argued that the actual percentage of people living below the poverty line is higher than government estimates, with the percentage placed at 56-65\% and rising. See: Foundation for Sustainable Development "Kenya: A develo pment overview", para 4, available at: <http://www.fsdinternational.org/country/kenya/ devissues> (last accessed 8 June 2013); J Kiringai et al "Feminisation of poverty in Kenya: Is fiscal policy the panacea or Achilles' heel?" (paper presented during the 5th PEP Research Network general meeting, Addis Ababa, Ethiopia, 18-22 June 
officially estimated poverty rate of 48 per cent in $1981 .^{2}$ According to data from the International Fund for Agriculture and Development, the overall poverty situation is worsening, rather than improving as is the trend in other developed and developing states, with estimates that, since the post-election crisis of 2008, the poverty headcount has increased by 22 per cent and the measure of severe poverty has gone up by a startling 38 per cent. ${ }^{3}$ The United Nations Development Programme (UNDP)'s Human Development Index (HDI, which measures development in terms of life expectancy, educational attainment and standards of living) has consistently ranked Kenya as a low human development country. In 2013, Kenya was 145th among the 186 ranked countries of the world, ${ }^{4}$ showing a slight human development regression from its previous position of 143 out of 187 countries in $2011^{5}$ and 128 out of 169 in $2010 .^{6}$

Poverty and socio-economic marginalization have been exacerbated in the recent past by the explosion of ethnic violence following: the bungling of the 2007 presidential elections; 7 rampant and runaway corruption that has debilitated

contd

2006), available at: <http:/www.pep-netorg/sites/pep-net.org/files/typo3doc/pdf/files_ events/5th_ethiopia/Kiringai.pdfs (last accessed 13 June 2015).

2 See The World Bank Poverty Reduction and Economic Management Unit "Kenya poverty and inequality assessment: Synthesis report" (Africa region report, June 2008) at ii, available at: <http://siteresources.worldbank.org/INTAFRREGTOPGENDER/Resources/PAKENYA.pdf (last accessed 13 June 2015).

3 See International Fund for Agriculture and Development "Kenya: Programme for rural outreach of financial innovations and technologies (PROFIT) programme design report" (May 2010) vol 1 at 5, available at: <http://www.ifad.org/operations/projects/design/100/kenya. pdf> (last accessed 8 June 2013).

4 UNDP "The rise of the South: Human progress in a diverse world" (Human Development Report 2013) at 146, available at: <http://hdr.undp.org/sites/default/files/reports/14/ hdr2013_en_complete.pdf> (last accessed 18 May 2015).

5 UNDP "Sustainability and equity: A better future for all" (Human Development Report 2011) at 126, available at: <http://hdr.undp.org/sites/default/files/reports/271/hdr_ 2011_en_complete.pdf> (last accessed 18 May 2015).

6 UNDP Human Development Report 2010 "The real wealth of nations: Pathways to human development" (2010) at 143-46, available at: <http:/hdr.undp.org/sites/default/files/ reports/270/hdr_2010_en_complete_reprint.pdf> (last accessed 13 June 2015). In the explanatory notes to the 2014 indicators for Kenya, UNDP contends that the ranking for Kenya in the $2013 \mathrm{HDI}$ is 147 out of 187 countries, a deterioration of two ranks; see UNDP "Sustaining human progress: Reducing vulnerabilities and building resilience Explanatory note to the $2014 \mathrm{HDR}$ composite indices - Kenya" at 2, available at: <http:// hdr.undp.org/sites/all/themes/hdr theme/country-notes/KEN.pdfs (last accessed 13 June 2015).

7 The Committee on the Convention on Elimination of all Forms of Racial Discrimination (CERD Committee) has noted that ethnic tensions and continued ethnic violence are due to the failure by the state to address ethuic and regional disparities in the enjoyment of economic and social rights, leading to resentment. The committee has therefore urged the state to enhance resource allocation to address disparities in access to socioeconomic goods and services, especially in historically marginalized areas and communities. This should be aimed at the reduction of inequality through employment and 
the government's resource capacity to provide basic services; climate change which has led to increased drought, crop failure and an exponential increase in the prices of basic commodities; ${ }^{8}$ international forces of globalization; skewed international trade; and the international economic downturn of 2008-09. ${ }^{9}$

Inequality, which is intricately linked to poverty and socio-economic marginalization, has also been a major challenge in achieving the objective of making Kenya a middle-income economy. Despite evidenced economic growth in the recent past, ${ }^{10}$ inequality ${ }^{11}$ is still highly entrenched in Kenyan political, economic, social and cultural spheres, with Kenya ranking among the most unequal countries in the world. ${ }^{12}$ In Kenya, inequality and deep human development disparities exist between rich and poor people, men and women, rural and urban areas, uptown and informal settlements, and between different regions and groups. The high inequality is intricately linked to the skewed distribution of state resources among different geographical areas and different communities in Kenya, leading to increased exclusion and marginalization. Inequality is manifested by huge disparities in income, lack of equal access to productive assets, social and political exclusion, and the inability of certain groups in society to access key social services. ${ }^{13}$

The World Bank's World Development Indicators 2011 indicate that inequality in Kenya is so high that, in the African region, it only compares favourably with that in South Africa, a country that had suffered many years of apartheid. The inequality Gini coefficient index ${ }^{14}$ for Kenya is 48 per

contd

education, and this effort should be anchored in the state's poverty reduction policies and strategies. See CERD Committee "Concluding observations of the Committee on the Elimination of Racial Discrimination: Kenya" (CERD/C/KEN/CO/1-4, September 2011), para 23, available at: <http://tbinternet.ohchr.org/_layouts/treatybodyexternal/ Download.aspx?symbolno $=\mathrm{CERD} / \mathrm{C} / \mathrm{KEN} / \mathrm{CO} / 1-4 \&$ Lang=En> (last accessed 13 June 2015).

8 See M Barasa "Rural poverty in Kenya” (2007) Contemporary Review 289 at 294-95.

9 CS Adam et al Kenya: Policies for Prosperity (2010) at 1.

10 UNDP indicators show that Kenya's gross national income per capita increased by about 11\% between 1980 and 2011; see UNDP "Sustainability and equity", above at note 5 at 2 .

11 According to Society for International Development "Pulling apart: Facts and figures on inequality in Kenya" (popular version, 2004) at 1, available at: <http://www.sidint. net/docs/pullingapart-mini.pdfs (last accessed 8 June 2013), inequality is: "The degree to which distribution of economic welfare generated in an economy differs from that of equal shares among its inhabitants ... It is observed not only in incomes but also in terms of social exclusion and the inability to access social services and socio-political rights by different population groups, genders and even races."

12 Tegemeo Institute Agricultural Policy and Development, Egerton University "Rural incomes, inequality and poverty dynamics in Kenya" (2009) at 2, available at: <http:// www.tegemeo.org/images/downloads/Working\%20papers/Tegemeo-WP30-Rural-incomesinequality-poverty-dynamics-Kenya.pdfs (last accessed 13 June 2015).

13 Id at 4.

14 The Gini coefficient varies within a range of 0 to 1 , with 0 indicating perfect equality between households, while 1 indicates perfect inequality. The Gini coefficient of most African countries ranges from about 0.40 to 0.50 , while most developed countries 
cent, as compared to 57.8 per cent for South Africa, 37.6 per cent for Tanzania and 29.8 per cent for Ethiopia. ${ }^{15}$ These dire inequality indicators are confirmed by the World Bank's poverty and inequality assessment report, which indicates that the ratio of consumption between the top and bottom 10 per cent of the Kenyan population stood at 20:1 in urban areas and 12:1 in rural areas. This compares adversely with the ratio of consumption in Tanzania that stood at 5:1 and that in Ethiopia, which stood at 3.3:1.16

The rampant poverty, inequality and political as well as socio-economic marginalization discussed above were the major drivers for a new political and socio-economic dispensation, which culminated in the promulgation in August 2010 of a new transformative constitution (the 2010 Constitution). The High Court of Kenya captured this starkly in the case of Satrose Ayuma as follows: "[t]he crave for the new Constitution in this country was driven by people's expectations of better lives in every aspect, improvement of their living standards and just treatment that guarantees them human dignity, freedom and a measure of equality."17

Entrenched, justiciable socio-economic rights (SERs) constitute one of the major tools in the 2010 Constitution aimed at reducing poverty and enhancing socio-economic equality. ${ }^{18}$ The main provisions on SERs in the 2010 Constitution are contained in the articles $21(2),{ }^{19} 43,{ }^{20}$

contd

have a coefficient ranging from 0.20 to 0.30 , indicating that developed countries have less inequality than developing countries. See id at 8. Oxfam Great Britain indicates that the Gini coefficient for rural areas in Kenya is 0.38 , while that of Nairobi is a staggering 0.59, indicating similar inequality levels to those in Johannesburg (South Africa) in the mid-1990s; see Oxfam Great Britain "Urban poverty and vulnerability in Kenya: Background analysis for the preparation of an Oxfam GB urban programme focused on Nairobi" (September 2009) at 3, available at: <http://www.irinnews.org/pdf/Urban_ Poverty_and_Vulnerability_in_Kenya.pdfs (last accessed 8 June 2013).

15 World Bank "World development indicators 2011" (April 2011) at 67-70, available at: <http://elibrary.worldbank.org/doi/book/10.1596/978-0-8213-8709-2> (last accessed 21 May 2015).

16 See World Bank "Kenya poverty and inequality assessment", above at note 2 at 3.

17 Satrose Ayuma and 11 Others $v$ The Attomey General and 2 Others High Court petition no 65 of 2010 at 22 .

18 The justiciability of the SERs in the constitution is affirmed by: their entrenchment as an integral part of the Bill of Rights; the constitutional empowerment of a wide array of parties to access courts in instances of the violation, infringement, denial or threatened infringement of these rights as per art 22; and the constitutional conferment of jurisdiction on the Kenyan courts to hear and determine applications for the violation of rights and to redress such violations through the adoption of effective remedies, as per art 23 read with art 165 of the constitution.

19 Art 21 deals with the implementation of rights and fundamental freedoms and subart (2) requires the state to "take legislative, policy and other measures, including the setting of standards, to achieve the progressive realisation of the rights guaranteed under article $43 "$.

20 Art 43 is entitled "Economic and social rights" and provides in art 43(1) that: "Every person has the right - (a) to the highest attainable standard of health, which includes the 
53(1)(a) ${ }^{21}$ and (b);22 they encapsulate the major SERs that have been entrenched in international and regional human rights instruments, as well as in the constitutions of countries that have entrenched SERs. ${ }^{23}$ The 2010 Constitution also acknowledges the importance of work / labour in the realisation of improved standards of living, and thus the transformation of the socioeconomic conditions of individuals and families, in the constitution's espousal of an extensive array of labour relations rights, such as rights to fair labour practices, fair remuneration, fair working conditions, formation of, and participation in, trade unions, as well as the right to strike. ${ }^{24}$

These constitutionally entrenched SERs are complemented and buttressed by the constitutional incorporation of SERs in international and regional legal instruments through article 2(6) of the 2010 Constitution, which provides that "[a]ny treaty or convention ratified by Kenya shall form part of the law of Kenya under this Constitution." 25 The Kenyan courts have affirmed the direct incorporation of international human rights law into the Kenyan domestic legal system via article $2(6)$ in several judgments, ${ }^{26}$ including in the Supreme Court where the chief justice, in a dissenting opinion, held that "[the Convention on the Elimination of all Forms of Discrimination against Women (CEDAW)] applies through the operation of article 2(6) of the Constitution of Kenya, having been acceded to by Kenya on 9th March

contd

right to healthcare services, including reproductive health; (b) to accessible and adequate housing, and to reasonable standards of sanitation; (c) to be free from hunger, and to have adequate food of acceptable quality, (d) to clean and safe water in adequate quantities; (e) to social security, and (f) to education." Art 43(2) prohibits the denial of emergency medical treatment and art 43(3) requires the state to provide social security to persons who are unable to support themselves and their dependants.

21 Every child's right to free and compulsory education.

22 Every child's right to basic nutrition, shelter and healthcare.

23 See the 1996 South African Constitution, secs 26, 27 and 28.

24 The 2010 Constitution, art 41.

25 A complete analysis of art 2(6) is beyond the scope of this article, but the author has dealt with this issue elsewhere; see N Orago "The 2010 Kenyan Constitution and the hierarchical place of international law in the Kenyan domestic legal system: A comparative perspective" (2013) 13 African Human Rights Law Joumal 415.

26 Among others: John Kabui Mwai and 3 Others $v$ Kenya National Examination Council and 2 Others High Court of Kenya at Nairobi, pet no 15 of 2011 at 6 ("Under article 2(6) of the constitution the convention forms part of our laws"); Okwanda $v$ The Minister of Health and Medical Services and 3 Others High Court of Kenya at Nairobi, pet no 94 of 2012, para 12 ("Apart from constitutional provisions governing economic and social rights, art 2(6) provides that treaties and conventions ratified by Kenya shall form part of the law of Kenya"); Mitu-Bell Welfare Society $v$ Attomey General and 2 others Nairobi pet no 164 of 2011 at 15 ("Article 2(5) and (6) of the constitution make the general rules of international law and any treaty or convention that Kenya has ratified part of the law of Kenya. Consequently, the state, state organs and all persons, in carrying out evictions, should do so in accordance with the United Nations Guidelines on Evictions"). 
1984".27 Some of the international legal instruments providing for SERs that have been ratified by Kenya include: the International Covenant on Economic, Social and Cultural Rights (ICESCR), ${ }^{28}$ the Convention on the Rights of the Child (CRC), ${ }^{29} \mathrm{CEDAW},{ }^{30}$ the Convention on the Rights of Persons with Disabilities, ${ }^{31}$ the relevant International Labour Organisation (ILO) conventions, 32 the African Charter on Human and Peoples' Rights (African Charter) ${ }^{33}$ and its Protocol on the Rights of Women in Africa, ${ }^{34}$ and the African Charter on the Rights and Welfare of the Child. ${ }^{35}$ These international legal instruments do not only form an important source of norms for the Kenyan courts, they also form an important guide in the interpretation and application of the SERs entrenched in the 2010 Constitution. This was

27 In the Matter of the Principle of Gender Representation in the National Assembly and the Senate Supreme Court of Kenya, advisory opinion, appln 2 of 2012, dissenting advisory opinion of Chief Justice Willy Mutunga, para 11.1.

28 Adopted and opened for signature, ratification and accession by GA res $2200 \mathrm{~A}$ (XXI) of 16 December 1966, entered into force 3 January 1976, assented to by Kenya 1 May 1972, available at: <http://www.ohchr.org/EN/Professionalinterest/Pages/CESCR.aspx> (last accessed 13 June 2015).

29 Adopted and opened for signature, ratification and accession by GA res 44/25 of 20 November 1989, entered into force 2 September 1990, in accordance with art 49. Ratified by Kenya 30 July 1990. Available at: <http:/www.ohchr.org/en/professional interest/pages/crc.aspx> (last accessed 13 June 2015).

30 Adopted and opened for signature, ratification and accessions 18 December 1979 , entered into force 3 September 1981, assented to by Kenya 9 March 1984, available at: <http://www.ohchr.org/EN/Professionalinterest/Pages/CEDAW.aspx> (last accessed 13 June 2015).

31 Adopted by GA res A/RES/61/106, 24 January 2007, signed by Kenya 30 March 2007 and ratified 19 May 2008, available at: <http://www.unhcr.org/refworld/docid/45f973632. html> (last accessed 8 May 2013).

32 Kenya has ratified 49 ILO conventions, 43 of which are in force and 6 have been denounced. Some of the conventions in force include: The Forced Labour Convention, 1930 (No 29); The Right to Organise and Collective Bargaining Convention, 1949 (No 98); Equal Remuneration Convention, 1951 (No 100); Abolition of Forced Labour Convention, 1957 (No 105); Discrimination (Employment and Occupation) Convention, 1958 (No 111); Minimum Age Convention, 1973 (No 138); and Worst Forms of Child Labour Convention, 1999 (No 182). For full ratification information, see: <http://www. ilo.org/dyn/normlex/en/f?p=NORMLEXPUB:11200:0::NO::P11200_COUNTRY_ID:103315> (last accessed 13 June 2015).

33 Adopted and opened for signature, ratification and accessions 1 June 1981, entered into force 21 October 1986, ratified by Kenya 23 January 1992, available at: <http://www.au. int/en/sites/default/files/banjul_charter.pdfs (last accessed 21 May 2015).

34 Adopted and opened for signature, ratification and accession 1 July 2003, entered into force 25 November 2005, ratified by Kenya 6 October 2010, available at: <http://www. au.int/en/sites/default/files/Protocol\%20on\%20the\%20Rights\%20of\%20Women.pdf> (last accessed 21 May 2015).

35 Adopted and opened for signature, ratification and accession 1 July 1990, entered into force 29 November 1999, ratified by Kenya 25 July 2000, available at: <http:/ www.au. int/en/sites/default/files/Charter_En_African_Charter_on_the_Rights_and_Wlefare_of_ the_Child_AddisAbaba_July1990.pdf> (last accessed 21 May 2015). 
affirmed by the Kenyan Supreme Court in an advisory opinion that "[i]t is clear to us that the Constitution of Kenya, 2010 which generously adopts such language of the international human rights instruments, draws inspiration from them". 36

The entrenched SERs entail a continuum of obligations on the state, contained in article 21 of the 2010 Constitution, which provides that "[i]t is a fundamental duty of the State and every State organ to observe, respect, protect, promote and fulfil the rights and fundamental freedoms in the Bill of Rights". ${ }^{37}$ This typology of obligations arising in the context of SER litigation was affirmed and elaborated as follows by the African Commission on Human and Peoples' Rights (African Commission) in the case of SERAC and Another $v$ Nigeria: "[i]nternationally accepted ideas of the various obligations engendered by human rights indicate that all rights - both [civil and politicar rights] and [SERs] - generate at least four levels of duties for a State that undertakes to adhere to a rights regime, namely the duty to respect, protect, promote, and fulfil these rights. These obligations universally apply to all rights and entail a combination of negative and positive duties." 38

Due to the similarities in the wording of the obligations, Kenyan courts should seek guidance from international, regional and comparative foreign national jurisprudence in interpreting these SERs obligations. ${ }^{39}$

The importance of SERs in the egalitarian transformation of Kenyan society was acknowledged as follows by the Kenyan High Court in John Kabui Mwai and Others $v$ The Attorney General and 2 Others (Kabui Mwai):

"In our view, the inclusion of [SERs] in the Constitution is aimed at advancing
the socio-economic needs of the people of Kenya, including those who are
poor, in order to uplift their human dignity. The protection of these rights
is an indication of the fact that the Constitution's transformative agenda
looks beyond merely guaranteeing abstract equality. There is a commitment
to transform Kenya from a society based on socio-economic deprivation to

36 The Principle of Gender Representation, above at note 27, para 52.

372010 Constitution, art 21(1). For an elaboration of the content of these obligations in relation to the SERs in the Kenyan Constitution, see Mitu-Bell Welfare Society, above at note 26 at 22-23.

38 Social and Economic Rights Action Centre and Another v Nigeria (2001) AHRLR 60 (ACHPR) 2001, paras 44-47.

39 For an elaboration of these obligations at the international level using the tripartite typology, see $A$ Eide "The human right to adequate food and freedom from hunger" (final report prepared for the UN Sub-Commission on Human Rights) E/CN.4/Sub.2/1987/23, available at: <http://www.fao.org/docrep/W9990E/w9990e03.htm> (last accessed 2 July, 2013); A Eide "Economic, social and cultural rights as human rights" in A Eide, C Krause and A Rosas (eds) Economic, Social and Cultural Rights: A Textbook (2001, Martinus Nijjhof) 9 at 22-28; D Bilchitz Poverty and Fundamental Rights: The Justification and Enforcement of Socio-Economic Rights (2007, Oxford University Press) at 184 and 195-96; MCR Craven The International Covenant on Economic, Social and Cultural Rights: $A$ Perspective on its Development (1998, Clarendon Press) from 330, among others. 
one based on equal and equitable distribution of resources. This is borne out by Articles 6(3) and 10(2)(b). The realisation of socio-economic rights means the realisation of the conditions of the poor and less advantaged and the beginning of a generation that is free from socio-economic need." 40

Therefore, the objective of the entrenchment of justiciable SERs in the 2010 Constitution, similar to that of other national jurisdictions that have entrenched such rights in their constitutions, is to facilitate the eradication of poverty and inequality, improve the overall standards of living of all people and ensure social justice. ${ }^{41}$ To achieve these objectives, a strong normative interpretive approach, with sufficient foundational standards and tests for the translation of abstract SER norms into tangible realities for the rights-holders, is crucial. ${ }^{42}$ This article proposes that the realisation of these goals in essence necessitates that, apart from the duty to realise SERs progressively, Kenya must explicitly adopt a minimum core approach to realising the entrenched SERs, an approach which requires the state, at the very least, to provide the most vulnerable of its citizens with the minimum essential levels of the entrenched SERs. ${ }^{43}$

40 Kabui Mwai, above at note 26 at 6.

$41 \mathrm{Z}$ Yacoob "The entrenchment and enforcement of socio-economic rights" (paper presented at the judges' conference to mark the inauguration of the new South African Constitutional Court building, 18-20 March 2004) at 3, available at: <http:// housingjustice.ca/wp-content/uploads/2012/03/the-entrenchment-and-enforcement-ofsocio-economic-rights.pdfs (last accessed 27 January 2013).

42 J Chowdhury "Judicial adherence to a minimum core approach to socio-economic rights: A comparative perspective" (paper presented at the fifth inter-university graduate student conference, Cornell Law School, March 2009) at 2, available at: <http:// scholarship.law.cornell.edu/lps_clacp/27> (last accessed 2 June 2013). Chowdhury contends (at 5-6) that, without identifying the tangible content of SERs and linking that content to the actual satisfaction of material needs, SERs are reduced to meaningless rhetoric.

43 S Rosa and M Dutschke (Children's Institute, University of Cape Town) "Child rights at the core: A commentary on the use of international law in South African court cases on children's socio-economic rights" (a Project 28 working paper, May 2006) at 12; RE Robertson "Measuring state compliance with the obligation to devote the 'maximum available resources' to realising economic, social and cultural rights" (1994) 16 Human Rights Quarterly 693 at 701. See also M Craven "Assessment of the progress on adjudication of economic, social and cultural rights" in J Squires, M Langford and B Thiele (eds) The Road to a Remedy: Current Issues in the Litigation of Economic, Social and Cultural Rights (2005, Australian Human Rights Centre, The University of New South Wales, in collaboration with the Centre on Housing Rights and Evictions) 27 at 39, who defines the minimum core content of rights as representing a quantitative or qualitative threshold of enjoyment; and the South African Human Rights Commission "7th report on economic and social rights: Millennium Development Goals and the progressive realisation of economic and social rights in South Africa: 2006-2009" (2010) at 14, where the commission affirms that the minimum core obligations are an inherent component of the progressive realisation test and that the two cannot be divorced from one another. 
This article aims to analyse the potential of the minimum core approach in the realisation of the entrenched SERs in the 2010 Constitution. After this introduction it analyses the foundational origins of the minimum core approach, before undertaking an analysis of the legitimacy of the development of the minimum core approach at the international level by the treaty monitoring mechanisms that have the mandate to interpret treaty provisions and how this percolates to the national level. Taking this legitimacy into account, the article then analyses the viability of the adoption of the minimum core approach in Kenya, before considering the embryonic jurisprudence of the Kenyan courts in relation to the minimum core approach. There follows an examination of the minimum core approach in two comparative jurisdictions: South Africa where the Constitutional Court has failed to embrace the minimum core approach; and Colombia, where the Constitutional Court has adopted a wholehearted espousal of the minimum core approach in its SER jurisprudence. The article thus proposes that Kenya should follow the Colombian example and adopt the minimum core approach with the aim of enhancing the achievement of the transformative aspirations of the 2010 Constitution. The article closes with a short conclusion.

\section{THE FOUNDATIONAL ORIGINS OF THE MINIMUM CORE OBLIGATIONS}

The minimum core approach entails two related components: the minimum core content that defines the nature or essential elements of an SER without which the right loses its substantive significance as a human right; and the minimum core obligations, which are the immediate measures a state must put in place to realise the minimum essential levels of an SER. ${ }^{44}$ The minimum core approach was developed by the Committee on Economic, Social and Cultural Rights (CESCR) in its effort to establish a minimum legal substance for the SERs entrenched in the ICESCR, with the aim of enhancing the prioritization of the socio-economic needs of most poor and vulnerable groups. ${ }^{45}$ It was developed as an intrinsic component of the standard of "progressive realisation" and the CESCR determined it as follows: "[a] minimum core obligation to ensure the satisfaction of, at the very least, minimum essential levels of each of the rights is incumbent upon every state party. Thus, for example, a state party in which a significant number of individuals are deprived of essential foodstuffs, of essential primary healthcare, of basic shelter and housing, or of the most basic form of education is, prima facie, failing to discharge its obligations under the [ICESCR]." 46

44 A Chapman and S Russell "Introduction" in A Chapman and S Russell (eds) Core Obligations: Building a Framework for Economic, Social and Cultural Rights (2002, Intersentia) 1 at 9.

45 KG Young Constituting Economic and Social Rights (2012, Oxford University Press) at 67-68.

46 Gen Comm No 3, para 10. 
The CESCR further stated that a reading of the ICESCR obligations devoid of the minimum core is tantamount to depriving them of their raison d'être. The committee has thus been at the forefront of developing a comprehensive minimum core jurisprudence detailing the content of the SERs in the ICESCR. ${ }^{47}$ The importance of developing the minimum core content of SERs was affirmed by Phillip Alston, who argues that the logical implication of terming SERs as rights is that SERs must give rise to some minimum entitlements, the absence of which must be considered to be a violation of states' SER obligations. ${ }^{48}$

The development of the minimum core relates closely to the "basic needs" paradigm developed under the 1976 World Employment Conference, which espoused the commitment of all ILO member states to provide:

"(i) the minimal consumption requirements needed for a physically healthy population (food, shelter, clothing); (ii) access to essential services and amenities (safe drinking water, sanitation, health and education); (iii) access of all to adequately remunerated employment opportunities; and, (iv) the satisfaction of the needs of a more qualitative nature (a healthy humane environment, and popular participation in making decisions that affect the lives and livelihoods of the people and their individual freedoms)." ${ }^{n 9}$

This basic needs paradigm, like the minimum core content approach, is based on human dignity and finds expression in the understanding that human dignity is entrenched in the material and non-material conditions of life required for human survival and happiness. ${ }^{50}$ As an ILO member state, Kenya is under an obligation to enforce these standards in accordance with its ILO commitments, a process of realisation which will go far in fulfilling the minimum core of the entrenched SERs.

The imperative for Kenya, and indeed other states, to adopt these basic minimum standards has been enhanced by the development in international

47 See for example: Gen Comm No 12 on the right to adequate food, paras 6, 8 and 33; Gen Comm No 13 on the right to education, para 57; Gen Comm No 14 on the right to the highest attainable standard of health, paras 43 and 47; Gen Comm No 15 on the right to water, para 37; Gen Comm No 17 on the author's right to benefit from the moral and material interests resulting from any scientific, literary or artistic production, para 39; Gen Comm No 18 on the right to work, para 31; Gen Comm No 19 on the right to social security, paras 59-61; and Gen Comm No 21 on the right of everyone to take part in cultural life, paras 55, 59 and 67.

48 P Alston "Out of the abyss: The challenges confronting the new United Nations Committee on Economic, Social and Cultural Rights" (1987) 9 Human Rights Quarterly 332 at $352-53$.

49 "Employment, growth and basic needs: A one-world problem" (report of the directorgeneral of the International Labour Office, 1976) at 7, quoted in D Olowu "Human development challenges in Africa: A rights-based approach" (2004) 5 San Diego International Law Journal 179 at 200.

50 Id at 201. 
human rights law, especially in the context of the minimum core approach, as evidenced in the General Comments of the CESCR, to the point that resource constraints are no longer a justification for a state to fail to meet its minimum core obligations. This progression commenced from the CESCR General Comment No 3, which allowed states to use the justification of resource constrains if they failed to realise their minimum core obligations. ${ }^{51}$ Despite this concession to resource constraints, the CESCR emphasized that states did not have carte blanche to use this as an absolute defence for their failure to realise SERs, and required a high threshold which would be fulfilled if a state was able to show that it had used all the resources at its disposal to satisfy its minimum core obligations as a matter of priority. ${ }^{52}$ In this context, the CESCR stated: "[i]n order for a state party to be able to attribute its failure to meet at least its minimum core obligations to a lack of available resources it must demonstrate that every effort has been made to use all resources that are at its disposition in an effort to satisfy, as a matter of priority, those minimum obligations." 53

The CESCR further emphasized that "even where the available resources are demonstrably inadequate, the obligation remains for a State Party to strive to ensure the widest possible enjoyment of the relevant rights under the prevailing circumstances". ${ }^{54}$ In this context, the minimum core approach affirms that, even in highly strained circumstances, the state retains an irreducible obligation to meet the minimum essential needs of those in the most deplorable socio-economic situations. 55

However, the committee contended in subsequent General Comments, such as General Comment No 14 and General Comment No 15, that the realisation of the minimum core was non-derogable and failure to realise it could not be justified by reliance on the lack of availability of resources. General Comment No 14 provides:

"If resource constraints render it impossible for a State to comply fully with its Covenant obligations, it has the burden of justifying that every effort has nevertheless been made to use all available resources at its disposal in order to satisfy, as a matter of priority, the obligations outlined above. It should be stressed, however, that a State party cannot, under any circumstances whatsoever, justify its non-compliance with the core obligations set out in paragraph 43 above, which are non-derogable. ${ }^{56}$

51 CESCR Gen Comm No 3, para 10, which states that "it must be noted that any assessment as to whether a State has discharged its minimum core obligation must also take account of resource constraints applying within the country concerned".

52 Ibid

53 Ibid.

54 Id, para 11.

55 Id, para 12; Chapman and Russell "Introduction", above at note 44 at 10.

56 CESCR Gen Comm No 14 (2000) covering the right to the highest attainable standards of health, para 47 (emphasis added). 
General Comment 15 further provides:

"To demonstrate compliance with their general and specific obligations, States must establish that they have taken the necessary and feasible steps towards the realisation of the right to water. In accordance with international law, a failure to act in good faith to take such steps amounts to a violation of the right. It should be stressed that a State party cannot justify its non-compliance with the core obligations set out in paragraph 37 above, which are non-derogable." 57

The principles and guidelines on SERs in the African Charter also acknowledge this progressive shift in the minimum core approach, by stating that they form part of a state's immediate obligations with regard to the implementation of SERs. ${ }^{58}$ The principles further state that these minimum obligations exist regardless of the availability of resources and are non-derogable:

"This [minimum core] obligation exists regardless of the availability of resources and is non-derogable. When a State claims that it has failed to realise minimum essential levels of [SERs] it must be able to show that it has allocated all available resources towards the realisation of these rights, and particularly towards the realisation of the minimum core content. Where the State does suffer from demonstrable resource constraints, caused by whatever reason, including economic adjustment, the State should still implement measures to ensure the minimum essential levels of each right to members of vulnerable and disadvantaged groups, particularly by prioritising them in all interventions. ${ }^{n 9}$

The progressive development in the minimum core approach discussed above has been reiterated by the UN special rapporteur on SERs, Danilo Turk, who contends that "[s]tates with specific legal obligations to fulfil [SERs] are obliged, regardless of the level of economic development, to ensure respect for minimum subsistence rights for all".60 The minimum core approach calls for

57 CESCR Gen Comm No 15 (2003) covering the right to water, para 40 (emphasis added).

58 African Commission on Human and Peoples' Rights 'The principles and guidelines on the implementation of economic, social and cultural rights in the African Charter on Human and Peoples' Rights" (adopted May 2010), para 16, available at: <http:// www.achpr.org/files/instruments/economic-social-cultural/achpr_instr_guide_draft_esc_ rights_eng.pdfs (last accessed 13 June 2015).

59 Id, para 17 (foomotes omitted).

60 Second progress report prepared by Danilo Turk, special rapporteur, UN Commission on Human Rights, Sub-Commission on Prevention of Discrimination and Protection of Minorities, E/CN.4/Sub.2/1991/17, para 52(d), available at <http://www.unhchr. ch/huridocda/huridoca.nsf/\%28Symbol\%29/E.CN.4.SUB.2.1991.17.En?Opendocument> (last accessed 10 June 2013). See also Limburg Principles on the Implementation of the International Covenant on Economic, Social and Cultural Rights, principle 25, available at: <http://www.acpp.org/RBAVer1_0/archives/Limburg\%20Principles.pdf> (last accessed 13 June 2015); and Maastricht Guidelines on Violations of Economic, Social and Cultural 
resource allocation to be prioritized in the realisation of the minimum essential goods and services to the most vulnerable in society, and also entails a stricter standard of judicial review in relation to the courts' enforcement of entrenched SERs. ${ }^{61}$ The jurisprudence shows the shift in international obligations with regard to the realisation of the minimum essential elements of SERs; it is thus imperative that Kenya take this into account when developing the framework for the implementation of entrenched SERs, as well as in SER adjudication.

There are several advantages in Kenya, and indeed any state with justiciable SERs, adopting the minimum core approach with the aim of uplifting the living standards of the poor, vulnerable and marginalized groups in society. It has been argued that the minimum core approach, with its clear specification of the minimum essential elements that the state must provide, gives the government a better standard with which to monitor implementation and provides better protection for SERs generally, and of the basic needs of vulnerable groups in particular. ${ }^{62}$ This is starkly captured by Danie Brand who contends that the interpretation and enforcement of entrenched SERs should, in the first instance, be aimed at "the creation of a society that provides for everyone's basic needs, and that protects everyone against deprivation". ${ }^{63} \mathrm{He}$ argues that a court, in undertaking SER litigation, must determine whether the state is pursuing its constitutionally mandated goal correctly in its policies, and in doing so must, of necessity, develop a

contd

Rights, guideline 9, available at: <https:/www1.umnedu/humants/instree/Maastricht guidelines_html> (last accessed 13 June 2015).

61 S Liebenberg "The value of human dignity in interpreting socio-economic rights" (2005) 21 South African Journal on Human Rights 436.

62 For a more complete development of these arguments, see Bilchitz Poverty and Fundamental Rights, above at note 39 at 150-66 and 221; id "Health" in S Woolman et al (eds) Constitutional Law of South Africa (2nd ed, 2009, Juta) chap 56A at 31-32, where Bilchitz avers that one of the evils sought to be remedied by the introduction of the minimum core concept was the lack of practical benchmarks against which to evaluate state efforts to realise entrenched SERs.

63 D Brand "The proceduralisation of South African socio-economic rights jurisprudence or 'what are socio-economic rights for?'" in $\mathrm{H}$ Botha, $A$ van der Walt and $\mathrm{J}$ van der Walt (eds) Rights and Democracy in a Transformative Constitution (2003, Sun Press) 33 at 36-37. He emphasizes that the real problem to be targeted by efforts aimed at the realisation of SERs should be deprivation and hardship itself. He contends that, in adopting the reasonableness approach, the South African Constitutional Court distanced itself from the concrete particular realities of hunger, homelessness, disease and illiteracy with which the entrenchment of SERs was intended to deal. He enumerates (at 51-56) the negative effects of the reasonableness approach to be: the failure to enhance the realisation of the transformative potential of the constitution; the discouragement of future creative SER litigation aimed at effecting social change; the burdening of indigent litigants with the burden to prove the unreasonableness of state policy; the availability of limited tools for the courts to deal with subsequent SER litigation; and the lack of substantive standards to guide the state in future socio-economic policy-making. 
substantive content to the entrenched SERs. ${ }^{64}$ This has also been affirmed by Sandra Liebenberg who, in her analysis of the Soobramoney judgment, argued that the failure by the South African Constitutional Court (SACC) to expound on the nature, scope and content of the right to health left the state with no clear guidelines for its implementation, thus adversely affecting the capacity of the right to exert a fundamental influence on the state's decision-making concerning social programmes and budgetary allocations. ${ }^{65}$

The minimum core approach makes it possible for the courts to adopt a more stringent scrutiny in evaluating the state's defences for the nonrealisation of the minimum essential needs of the most vulnerable. ${ }^{66}$ It further makes it more feasible for the courts to provide the government with clear timelines within which to implement the court's orders, and also enables the court properly to monitor and supervise compliance with its own orders. ${ }^{67}$ This is in line with the constitutional requirement that the courts grant effective relief in instances of violations of constitutionally entrenched human rights and fundamental freedoms. ${ }^{68}$

\section{THE LEGITIMACY OF THE DEVELOPMENT OF THE MINIMUM CORE APPROACH AT THE INTERNATIONAL LEVEL AND WHY KENYA SHOULD ADOPT THE APPROACH}

The most important question at this juncture is whether there is any obligation on Kenya to adopt the minimum core approach, and how the adoption of the approach can spur on the implementation of SERs. This question raises three pertinent issues for discussion. First, from where do the treaty monitoring mechanisms, especially the CESCR, obtain their legitimacy to interpret the relevant international legal instruments and how does this warrant states' voluntary compliance with the monitoring bodies' interpretations? Secondly, do the monitoring bodies, in their interpretation of the ICESCR and in the development of the minimum core obligations, employ interpretive approaches that are consistent with the rules of interpretation accepted under international law? Thirdly, what has been the practice of states in relation to the

64 Id at 44-51. He points out that the major failure of the South African Constitutional Court's reasonableness approach is the failure to develop substantive content for SERs. He states (at 48-49) that, due to this failure, the court cannot, in the conduct of its reasonableness analysis, determine whether the state's policy in question is capable of achieving the relevant right (as the substantive content of the essential referent right is not developed), leaving the court only with the option of evaluating whether the policy in question is rational, coherent, comprehensive and inclusive, among other good governance standards.

65 S Liebenberg Socio-Economic Rights Adjudication under a Transformative Constitution (2010, Juta \& Co) at 142.

66 Bilchitz Poverty and Fundamental Rights, above at note 39 at 146.

67 Ibid.

682010 Constitution, art 23. 
general recommendations that have been adopted by treaty monitoring bodies, especially the CESCR?

These issues are broadly dealt with below, with the objective of making a case for the adoption of the minimum core approach in Kenya.

\section{Interpretive legitimacy and authority of treaty monitoring bodies}

The treaties detailing SERs have reporting mechanisms created by state parties to monitor state implementation of the treaties, be it through state reporting, consideration of individual, group or state communications, or by conducting inquiries. The mandates of these treaty bodies give them the authorization to interpret the provisions of relevant treaties in line with their experiences through the formulation of General Comments. Part IV of the ICESCR mandates the Economic and Social Council (ECOSOC) to receive state reports ${ }^{69}$ and to produce General Comments to assist states and UN specialized agencies in implementing their obligations under the covenant. ${ }^{70}$

In order to enhance the implementation of its mandate, ECOSOC created the CESCR in May 1986, ${ }^{71}$ to take over from the ECOSOC Sessional Working Group of Government Experts that had been monitoring implementation on behalf of ECOSOC from $1976 .{ }^{72}$ The committee is composed of experts with recognized competence in SERs; they act in their personal capacity, which enhances their impartiality and independence. ${ }^{73}$ They also represent different geographical, legal and social systems of the world, enhancing the consideration of different world views in the committee's interpretation of covenant provisions. The CESCR is mandated to submit to ECOSOC a report of its activities, including a summary of its consideration of state reports and general recommendations, so as to facilitate ECOSOC in its responsibilities under articles 22-22 of the covenant. ${ }^{74}$ Alston simplifies this mandate into the following responsibilities: "(1) the clarification of the normative content of each of the relevant rights; (2) the encouragement of more meaningful reporting by State parties; (3) the improved cooperation with relevant UN bodies, including the specialised agencies; (4) the facilitation of greater input from non-governmental organisations; and (5) the effective follow-up to the examination of States' reports." 75

Though the CESCR was not specifically established in the ICESCR, as is the norm with other treaty monitoring bodies, its establishment was authorized and done in accordance with the covenant. The fact that its work is mainly

69 ICESCR, arts 16-20.

70 Id, arts 21-22.

71 It was established under ECOSOC res $1985 / 17$ of 28 May 1985 , ESC res $1985 / 17,1985$ UN ESCOR supp (No 1) at 15, UN doc E/1985/85 (1985).

72 See Alston "Out of the abyss", above at note 48 at 333. He details (at 335-49) the failures of the working group which led to the establishment of the CESCR.

73 ESC res 1985/17, above at note 71, para b.

74 Id, para $\mathrm{f}$.

75 Alston "Out of the abyss", above at note 48 at 349-79. 
aimed at assisting ECOSOC, the body that was conventionally mandated to monitor the implementation of ICESCR, does not detract from the authenticity of its mandate and the legitimacy of its interpretation of the covenant as is encompassed in its Concluding Observations and General Comments.

The legitimacy of the other treaty monitoring bodies which have similarly adopted the minimum core approach in the interpretation of the SERs in their relevant treaties, such as the CEDAW Committee, CRC Committee and the Committee on the Rights of Persons with Disabilities (CRPD Committee), have not generated much debate, as their mandates are provided for within the text of the relevant treaties. The CEDAW Committee is established under part $\mathrm{V}$ of the convention ${ }^{76}$ and article 21 provides for its mandate to make suggestions and adopt General Recommendations based on the consideration of state reports and information received from state parties. The acceptability of its General Recommendations can be gleaned from the fact that, even though CEDAW provides for a system of dispute resolution in instances of a difference in interpretation or application, the system has so far not been used to challenge any of the interpretations of the convention as provided by the CEDAW Committee. ${ }^{77}$

The CRC Committee is established under part II of the CRC. ${ }^{78}$ It is mandated to receive and consider state reports ${ }^{79}$ and to make General Recommendations based on information received from state parties and other specialized agencies in accordance with articles 44 and 45.80 Lastly, the CRPD Committee is established under article 34 of the convention with the task of considering state reports; ${ }^{81}$ it can also make suggestions and General Recommendations based on the examination of state reports and on information received from state parties. ${ }^{82}$

Since states have ratified these relevant treaties knowing the mandates of the monitoring bodies, they have, in good faith, undertaken to be bound to accept the authenticity and legitimacy of the General Recommendations emanating from them, and should thus be expected to be bound, or at least to be authoritatively persuaded, by the General Recommendations emanating from these bodies in good faith. In relation to the CESCR, this conclusion is supported by Alston and Quinn, who contend that, if state parties have ratified the covenant in good faith, and given the CESCR genuine authority as the body charged with interpreting the covenant provisions, then they must, as a necessity, be bound by the interpretation that the CESCR has accorded to the treaty,

CEDAW, art 17.

Id, art 29(1).

CRC, art 43.

Id, art 44 .

Id, art 45(d).

81 Convention on the Rights of Persons with Disabilities, arts 35-36.

82 Id, art 39. 
including the incorporation of the minimum core approach into state parties' SER obligations. ${ }^{83}$

\section{Compliance of the treaty monitoring bodies with rules of interpretation under international law}

On this second question, SERs are part of human rights law, which is part of the larger body of international law. Accordingly, the customary rules of treaty interpretation, albeit with a little adjustment due to the unique nature of human rights instruments, also apply to SERs. ${ }^{84}$ The customary rules of interpretation are encapsulated in articles 31-33 of the Vienna Convention on the Law of Treaties. Article 31(1) is especially informative as it calls for treaty provisions to be interpreted in good faith taking into account not only their ordinary meaning (literal interpretation), but also the objects and purpose of the relevant treaty (teleological interpretation) and the context in which the treaty is applied (systematic interpretation). To support article 31 further, the Vienna Convention provides other aids to interpretation, which include the preparatory works of the treaty and the circumstances of its conclusion. ${ }^{85}$

In using these rules to interpret human rights treaties, the monitoring bodies are expected to take into account the objects and purposes of the relevant treaty, and to undertake an expansive interpretation aimed at providing the greatest and most effective protection to individuals and groups. ${ }^{86}$ This should be done in accordance with the principle of good faith, which requires that

83 P Alston and G Quinn "The nature and scope of state parties obligations under the International Covenant on Economic, Social and Cultural Rights" (1987) 9 Human Rights Quarterly 156 at 160-61.

84 MM Sepulveda The Nature of the Obligations under the International Covenant on Economic, Social and Cultural Rights (2003, Intersentia) at 74 and 77-87. She undertakes an extensive discussion, quoting several authors and decisions of the International Court of Justice, in particular the advisory opinion of 28 May 1951 on the reservation to the Convention on the Prevention and Punishment of the Crime of Genocide, which indicate the special nature of human rights treaties as treaties granting protection to individuals and groups who are not parties to the treaty but who nevertheless need protection.

85 Vienna Convention on the Law of Treaties, art 32.

86 Sepulveda The Nature of the Obligations, above at note 84 at 79 . She quotes the European Court in Soering $v$ United Kingdom 161 Eur Ct HR (ser A) (1989) where the court stated, at para 87, that: "In interpreting the Convention, regard must be had to its special character as a treaty for the collective enforcement of human rights and fundamental freedoms ... thus the object and purpose of the Convention as an instrument for the protection of individual human beings requires that its provisions be interpreted and applied so as to make its safeguards practical and effective." She further discusses the need for an evolutive interpretation of human rights treaties, taking into account developments in international human rights law and in the context of present day conditions, basically adopting the "living instrument principle". She refers (at 80) to the European Court case of Airey $v$ Ireland 32 Eur Ct HR (ser A) (1979) where the court stated in relation to the European Convention on Human Rights, at para 26, that "the Convention must be interpreted in the light of present day conditions and it is designed to safeguard the individual in a real and practical way as regards those areas with which it deals". 
positive rules of law contained in treaties are interpreted and applied honestly, fairly and reasonably. ${ }^{87}$ The customary norms of treaty interpretation as well as the principle of good faith have been effectively employed in practice by the treaty monitoring bodies in interpreting the contents of the relevant legal instruments. A case in point is the CESCR which has undertaken an expansive interpretation to make the entrenched SER provisions effective and practical in the protection of the relevant groups and individuals. This can be seen in the development of states' minimum core obligations, which are aimed at giving content to SERs to make them practical in the protection of marginalized and vulnerable groups. ${ }^{88}$

\section{State practice in relation to the General Comments of treaty monitoring bodies}

On this third issue, and as discussed above, the treaty monitoring bodies are authoritatively mandated to monitor the implementation of the relevant treaties and, as such, have the authority to interpret the scope of the treaties' provisions through General Comments. Through their General Comments, the monitoring bodies have developed the minimum core obligations as being implicit in the obligations of states in accordance with the relevant treaties. $^{89}$ Even though under traditional intemational law these General Comments are not legally binding on member states, it is beyond doubt that they carry considerable legal clout. ${ }^{90}$ This is reflected in the wide acceptance of the monitoring bodies' General Comments by state parties to those relevant treaties. ${ }^{91}$ Kenya, as a state party to the relevant treaties is, therefore, under an obligation to fulfil its obligations under these treaties in good faith, including the realisation of its minimum core obligations on SERs through the adoption of the minimum core approach. Failure to do so will be indicative of bad faith. ${ }^{92}$

87 Sepulveda, id at 76.

88 CESCR Gen Comm No 9, paras 11 and 15; Gen Comm No 12, para 6; and Gen Comm No 14, para 11.

89 CESCR Gen Comm No 3, para 10.

90 Sepulveda The Nature of the Obligations, above at note 84 at 88 ; Craven The International Covenant, above at note 39 at 91 .

91 See L Chenwi "Monitoring the progressive realisation of socio-economic rights: Lessons from the United Nations Committee on Economic, Social and Cultural Rights and the South African Constitutional Court" (2010) at 4-5 (on file with author); and Craven, id at 92. Both authors contend that the endorsement of the General Comments of the CESCR by ECOSOC and the UN General Assembly, where a number of state parties participate in the consideration of the committee's report, is a clear indication of acceptance of the interpretation given to the ICESCR provisions by the committee. See also Chowdhury "Judicial adherence", above at note 42 at 5 , who states that national courts have been known to draw from the CESCR's General Comments when they adopt the minimum core approach.

92 Sepulveda The Nature of the Obligations, above at note 84 at 88 . 


\section{AN ANALYSIS OF THE VIABILITY OF THE ADOPTION OF THE MINIMUM CORE OBLIGATIONS IN THE DEVELOPMENT OF KENYA'S SER JURISPRUDENCE}

It is generally accepted that, where there is doubt with regard to the meaning or import of domestic law, that law should be interpreted in a way that gives credence to the relevant international obligations accruing to the state due to its ratification of international legal instruments. ${ }^{93}$ As noted above, Kenya has assumed international SER obligations by ratifying several international and regional legal instruments. The 2010 Constitution acknowledges that all these international human rights instruments, and all the general rules of international law accruing from them, form part of Kenyan law. ${ }^{94}$ The SER provisions of these ratified international legal instruments have been interpreted, by the authoritative mechanisms responsible for monitoring the implementation of those instruments, to include the minimum core obligations discussed above. In its development of the minimum core approach, the CESCR endorsed the approach as a guide to states in their domestic implementation and enforcement of SERs ${ }^{95}$ with the objective of responding to the perennial SER justiciability challenges of lack of clarity and content.96 Katharine Young, in her support of the applicability of the minimum core approach at the national constitutional level, contends that the approach can assist national courts in three aspects of adjudicating SERs: the determination of the state's obligations to respect such rights negatively; the determination of the state's obligation to "progressively realise" such rights in their protection and fulfilment; and the determination of the state's obligation to justify any limitation of SERs, using a more stringent external limitation clause such as article 24 of the 2010 Constitution. ${ }^{97}$ Taking into account the doctrine of good faith, Kenya must thus be bound to adopt the interpretation of the monitoring bodies on the minimum core obligations and implement them in its legislative, policy and programmatic framework aimed at the realisation of the entrenched SERs, as well as in the adjudicatory practices of the courts. ${ }^{98}$

93 Alston and Quinn "The nature and scope", above at note 83 at 171.

94 See the discussion of art 2(6) of the constitution in the "Introduction" to this article.

95 See CESCR Gen Comm No 12, para 33; Gen Comm No 14, para 60; Gen Comm No 15, para 57; and Gen Comm No 18, para 49.

96 Young Constituting Economic and Social Rights, above at note 45 at 78-79.

97 Id at 82-83. In its limitations role, the minimum core approach reverses the onus of proof in SER litigation, with the requirement that, once the claimant has shown that the minimum core of any particular right has not been protected, the onus reverts to the state to show either that it has put in place reasonable legislative measures within its available resources to realise the right in question, or to justify the reasonableness of its limitation of the right in question. In this way, the minimum core turns the SER paper rights into practical reality for claimants.

98 For the importance of adopting the minimum core obligations, see: Limburg Principles, above at note 60, principle 5; and Maastricht Guidelines, above at note 60 , guideline 8 . 
An expansive reading of the SERs entrenched in the 2010 Constitution to incorporate the minimum core approach is envisaged by the constitution itself, especially article 20(2) which provides for the enjoyment of rights in the constitution to the greatest extent consistent with the nature of the rights. This is further buttressed by article 20(3)(b) which calls for the adoption of an interpretation that most favours the enforcement of rights, ${ }^{99}$ and article $24(2)$ (c) which provides that any provision in legislation limiting a right or fundamental freedom must not limit the right to such an extent that derogates from the right's core or essential content. To enhance the standard of living of vulnerable groups and communities, the constitution also entrenches the state's duty to provide for their needs as follows: "[a]ll State organs and all public officers have the duty to address the needs of vulnerable groups within society, including women, older members of society, persons with disabilities, children, youth, members of minority or marginalised communities, and members of particular ethnic, religious or cultural communities."100

The state's obligation to enhance the socio-economic condition of vulnerable groups and communities is further buttressed by article 20(5)(b) which requires the state to prioritize the allocation of resources towards the realisation of rights as follows: "[i]n allocating resources, the State shall give priority to ensuring the widest possible enjoyment of the right or fundamental freedom having regard to prevailing circumstances, including the vulnerability of particular groups or individuals."

It therefore follows that, for the entrenched SERs to achieve the purpose for which they were intended, in accordance with article 19(2) of the 2010 Constitution, 101 the minimum core obligations envisaged by the entrenched SERs must be upheld. This proposal is in line with the recommendations of the CESCR which has been categorical that an understanding or reading of substantive SERs which does not incorporate the minimum core deprives SERs of their raison d'être. In this vein, the CESCR has emphasized the necessity of an extensive and inclusive interpretation of SER obligations, and has categorically called on states not to interpret SER provisions in a way that

contd

See also CESCR Gen Comm No 9, paras 3 and 15, which require states to interpret domestic legal provisions in a manner that gives credence to their international law obligations and discourages reliance on national laws to defeat international legal obligations.

99 See also 2010 Constitution, art 259(1) which calls for the provisions of the constitution to be construed in a manner that: promotes its purposes, values and principles; advances the rule of law and the fundamental rights in the Bill of Rights; permits the development of law, and contributes to good governance.

100 Id, art 21(3).

101 This article provides: "The purpose of recognizing and protecting human rights and fundamental freedoms is to preserve the dignity of individuals and communities and to promote social justice and the realisation of the potential of all human beings." 
deprives them of their meaningful content, rendering them ineffective and illusory. ${ }^{102}$

The adoption of the minimum core approach necessitates the development of the substantive content of SERs. This, however, raises another set of questions: how pragmatically to determine the substantive content of the rights; and how a determination of the substantive content of SERs will be beneficial to Kenyans, especially the poor, vulnerable and marginalized. The first question was one of the major concerns that led the SACC to decline to adopt the minimum core approach to the interpretation of SERs. ${ }^{103}$ It raises the dilemma of how, in a diverse society with different understandings of minimum essential needs for human survival and well-being, a detailed and comprehensive theory of value can be imposed to determine what the minimum core content of each SER entails.

However, in response to these concerns, the very entrenchment of justiciable SERs in the 2010 Constitution can be said to acknowledge the very diversity of society and that different individuals and groups have different needs that must be provided for. These needs can be met either through the adoption by the state of relevant legislative, policy and programmatic frameworks to provide an enabling environment to allow people to meet their basic socioeconomic needs using their own resources, or through the actual provision of basic socio-economic goods and services to individuals and groups who are unable to provide for themselves. This acknowledgment resonates perfectly with the international obligations of the state to respect, protect, promote and fulfil SERs, as is entrenched in article 21(1) of the 2010 Constitution. ${ }^{104}$ This, in essence, therefore places responsibility for the development of the content of SERs squarely on the doorstep of the government, especially the political institutions which bear the major responsibility for developing and implementing measures aimed at the realisation of SERs. ${ }^{105}$

How then will the political institutions determine the content of SERs? The author submits that there is no need to reinvent the wheel. A lot of work has already been done in the international arena, especially by the CESCR, the African Commission ${ }^{106}$ and other international experts, ${ }^{107}$ to develop the minimum essential elements for most of the SERs entrenched in the

102 CESCR Gen Comm No 14, para 31; Gen Comm No 13, para 44; Gen Comm No 9, para 11; and Gen Comm No 3, para 9.

103 Govermment of the Republic of South Africa v Grootboom and Others 2001 (1) SA 46 (CC), paras 32-33.

104 See 2010 Constitution, art 21(1).

105 Liebenberg Socio-Economic Rights Adjudication, above at note 65 at 39-42.

106 See "The principles and guidelines", above at note 58, which developed the minimum core obligations of the SERs entrenched in the African Charter in paras 17 (general), 59 (work), 67 (health), 71 (education), 79 (housing), 82 (social security), 86 (food), 92 (water and sanitation) and 97 (family life).

107 See generally Chapman and Russell (eds) Core Obligations, above at note 44; P Hunt Reclaiming Social Rights: International and Comparative Perspectives (1996, Dartmouth). 
constitution. All that is required of the state, therefore (and this can be done almost immediately, without raising arguments about the availability of resources), is to use available international and regional material to develop the minimum essentials to the entrenched SERs, taking into account Kenya's peculiar historical context, priorities and long-term objectives. This should be done specifically by the state's political institutions, especially the legislature and the executive, in their development of the legislative, policy and programmatic framework for the realisation of the SERs entrenched in the 2010 Constitution. If this is done in an inclusive process allowing for the participation of all Kenyan people in accordance with articles 10 , $118-19,{ }^{108} 196,{ }^{109} 201^{110}$ and $232(1)(d)^{111}$ of the constitution, the state will be able to develop a detailed and comprehensive standard detailing the minimum core content of the SERs that is inclusive and acceptable to all Kenyans. As part of the process of developing the minimum core content of SERs, the state must incorporate the requisite achievable targets, indicators, benchmarks and specific timelines to provide guidance in the implementation, monitoring and evaluation of the plan of action, as well as enabling the public and other watchdog institutions to monitor progress. ${ }^{112}$ The minimum core content, as developed by the political institutions, will then be polished by the courts over time, as and when cases dealing with specific SERs come to the courts for interpretation.

The adoption of the minimum core approach will be beneficial to the poor, and vulnerable and marginalized individuals, groups and communities because it will breathe life into abstract constitutional provisions and ensure that the government has clear criteria within which to structure its legislation, policies and programmes aimed at implementing the entrenched SERs. Such criteria will involve the development of the content of the abstract SERs in the constitution to ensure that both the citizenry and the government have a clear understanding of the nature, content and extent of the rights provided by the constitutional provisions and a clear understanding of the duties they impose on state institutions. Such criteria are also important for the donor community, international agencies, and national and international NGOs as they can then choose specific aspects within the criteria to fund and also have clear indicators for monitoring the state's policies and programmes for the implementation of SERs.

108 Requires Parliament to facilitate public participation and involvement in the legislative as well as other businesses of Parliament and its committees.

109 Requires county assemblies to facilitate public participation and involvement in the legislative as well as other businesses of the county assemblies.

110 Contains the principles of public finance which require openness and accountability, including public participation in financial matters.

111 Envisages public participation in the design of the policy and programmatic frameworks for the implementation of entrenched SERs.

$112 \mathrm{~S}$ Liebenberg "The interpretation of socio-economic rights" in Woolman et al Constitutional Law of South Africa vol 2 (2nd ed, 2009, Juta) chap 33 at 42. 


\section{EMERGING JURISPRUDENCE IN THE KENYAN COURTS IN RELATION TO THE MINIMUM CORE APPROACH}

Even though Kenya's SER jurisprudence is still in its tender years of development, the current constitution having only been promulgated in 2010, Kenyan courts have already shown a propensity towards an expansive and progressive interpretation of constitutional rights to accord with international law. These can be seen in Kabui Mwai where the court relied heavily on the education provisions of the ICESCR as well as the elaboration of the right to education in the CESCR's General Comment No 13 interpreting the right to education in article 43(1)(f) of the 2010 Constitution. ${ }^{113}$

Kabui Mwai dealt with a challenge to the state's policy to put in place a quota system to ensure equitable access to national secondary schools between primary school learners in public and private schools. ${ }^{114}$ The policy was challenged by the private schools as being discriminatory against their pupils and thus unconstitutional. ${ }^{115}$ In determining the case, the court affirmed the importance of the national values and principles of governance enshrined in article 10 (2)(b) of the 2010 Constitution, as well as the purposes for the constitutional recognition and protection of human rights: the preservation of human dignity; the promotion of social justice; and the realisation of the potential of all human beings as enshrined in article 19(2) of the constitution. ${ }^{116}$ The court further acknowledged that, in interpreting the Bill of Rights, it had to promote the values underlying an open and democratic society based on human dignity, equality, equity and freedom, as enshrined in article 20(4)(a) of the constitution, as well as abide by its duty to address the needs of vulnerable groups within society as per article 21(3) of the constitution. ${ }^{117}$ The court also recognized that the entrenchment of justiciable SERs in the constitution was aimed at advancing the socio-economic needs of the people, especially the poor, vulnerable and marginalized groups so as to uplift their human dignity, with the objective of achieving an egalitarian transformation of society. ${ }^{118}$

Having set this background, the court proceeded to adopt a substantive and contextual conception of equality, borrowing from the concept of "unfair discrimination" as propounded by the SACC in President of the Republic of South Africa and Another $v$ Hugo. ${ }^{119}$ Taking this into account, the court held that not all differential treatment resulted in the violation of the equality and nondiscrimination articles of the 2010 Constitution, and that the state could

113 Kabui Mwai, above at note 26 at 6-7.

114 See id at $1-2$.

115 Id at 2-4.

116 Id at 5.

117 Ibid.

118 Id at 6.

119 President of the Republic of South Africa and Another $v$ Hugo (CCT11/96) 1997 (4) SA 1, para 41 ; id at 8-9. 
legitimately put in place affirmative action, as is clearly authorized by article 27(6) of the constitution, to protect and uplift the situation of historically marginalized groups in society. ${ }^{120}$ The court thus held that, in order for it to achieve the transformative aspirations of the constitution, it had to temper merit with equity, as the previous policy based on merit alone had occasioned unfairness and prejudice to candidates from public schools who had to compete for the few slots available in national secondary schools from a point of disadvantage, due to a lack of necessary infrastructural facilities as well as financial and human resources. ${ }^{121}$

Did Kabui Mwai espouse or reject the minimum core approach? Jotham Arwa contends as follows: "[i]n the few cases that have been heard by the courts since the promulgation of the new constitution, the courts appear to have adopted an attitude that is hostile to the adoption of the minimum core approach. As has been illustrated by the decision in Kabui Mwai, the Kenyan Constitutional Court on 16 September 2011 rejected the application of the minimum core approach."122

In making this statement, Arwa did not point to any specific paragraph of the Kabui Mwai judgment or any other court documents on the case, nor did he mention any of the earlier cases where the Kenyan courts had categorically rejected the minimum core approach. His statement above might have been premised on the pronouncement of the court in Kabui Mwai that:

"The realisation of socio-economic rights means the realisation of the conditions of the poor and less advantaged and the beginning of a generation that is free from socio-economic need. One of the obstacles to the realisation of this objective, however, is limited financial resources on the part of the Government. The available resources are not adequate to facilitate the immediate provision of socio-economic goods and services to everyone on demand as individual rights. There has to be a holistic approach to providing socioeconomic goods and services that focus beyond the individual."

Socio-economic rights are by their very nature ideologically loaded. The realisation of these rights involves the making of ideological challenges which,

120 Kabui Mwai, id at9. The court stated: "When the Constitution was adopted, the framers knew, and clearly had in mind, the different status of persons in the society and the need to protect the weak from being overrun by those with ability. They had in mind the history of this country, both the differences in endowment either by dint of the region where one came from or as a function of other factors, which might necessitate special protection. Rightly or wrongly, and it is not for the court to decide, the framers of the Constitution manifestly regarded as inadequate a blanket right to equal treatment, and their intention was to remedy the perceived societal inequalities thus recognising the necessity of corrective measures ... It was out of the realisation that unequal people cannot be treated equally."

121 Id at 10-11.

122 JO Arwa "Litigating socio-economic rights in domestic courts: The Kenyan experience" (2013) 17 Law, Democracy and Development Joumal 419 at 435, available at: <http://www. saflii.org/za/journals/LDD/2013/20.pdfs (last accessed 13 June 2015). 
among others, impact on the nature of the country's economic system. This is because these rights engender positive obligations and have budgetary implications which require making political choices. In our view, a public body should be given appropriate leeway in determining the best way of meeting its constitutional obligations. ${ }^{123}$

The court may have erred in stating that SERs are ideologically loaded to the point of impacting on the nature of a country's economic system, but it was correct to point out that resources are an important component in the realisation of entrenched SERs and that, due to resource constraints, it would not have been possible to provide all the entrenched SERs to all people immediately on demand. This is the very reason why the standard of progressive realisation has been adopted both nationally and internationally in the realisation of SERs. Therefore, the court's contention that a holistic approach that focuses beyond the individual be adopted for the realisation of SERs did not necessarily mean that the court was rejecting the minimum core approach. In this context, it is submitted that Arwa's statement is not only misleading, but may actually be false, as the court in Kabui Mwai was never presented with a minimum core approach argument by any of the counsel in the case, and no submissions were made requiring the court to make a determination of the minimum core content of the right to education. The court was faced with an equality and non-discrimination controversy, which it dealt with substantively and progressively, taking into account Kenya's historical and prevailing contextual socio-economic situation and the values underpinning the constitution, as well as relying heavily on international and comparative law sources. It is thus incorrect to conclude that the court in Kabui Mwai rejected the minimum core approach to the realisation of SERs.

It is clear that the court in Kabui Mwai did not make any pronouncement with regard to the minimum core approach, but this does not answer the question as to the predisposition of the Kenyan courts towards the approach. A case in which the High Court of Kenya did make a pronouncement with regard to the minimum core approach is Federation of Women Lawyers (FIDA-K) where the court affirmed the state's obligation to realise the minimum core of rights entrenched in article 27 as follows:

"In order for a State to be able to attribute its failure to meet at least its minimum core obligations due to any event or circumstance, it must demonstrate that every effort has been made within its disposition in an effort to satisfy as a matter of priority the minimum obligations set out in Article 27 as a whole. It is clear from the extract from International Conventions that every party state is bound to fulfil a minimum core obligation by ensuring the satisfaction of a minimum enjoyment of the rights enshrined under Article 27."124

123 Kabui Mwai, above at note 26 at 6.

124 Federation of Women Lawyers and 5 Others $v$ Attomey General and Another (FIDA-K) High Court petition no 102 of 2011 at $47-48$. 
In this case, however, the court noted the difficulty of determining the minimum core for the realisation of the right to affirmative action due to differing societal needs, a challenge that requires a holistic assessment of the vulnerability of a variety of groups. The court then resorted to the standard of reasonableness, but retained the applicability of the minimum core approach in determining the reasonableness of a measure for the realisation of rights as follows: "[a]n issue which would arise is whether the measures taken by the State or State organ to realise the rights awarded by Article 27 are reasonable. In that regard we think there may be cases or situations where it may be possible and appropriate to have regard to the content of a minimum core obligation to determine whether the measures taken or to be taken are reasonable and satisfy the needs and aspirations of all vulnerable groups."125

The dictum from the Federation of Women Lawyers case is thus indicative of the applicability of the minimum core approach in the Kenyan context in relevant circumstances to enhance the protection of SERs.

Applicability of the minimum core approach was further affirmed in an equality and non-discrimination judicial review case, Jared Juma $v$ Kenya Broadcasting Corporation and 0thers. ${ }^{126}$ This case challenged an employment condition by the state broadcasting corporation that, for a person to qualify for appointment as the managing director of the corporation, they must be below the age of 45 years. The applicant argued that this was discriminatory and contrary to article 27 of the 2010 Constitution as it was introduced arbitrarily to give undue advantage to the acting managing director and to lock out competition for the position. ${ }^{127}$ In its determination of the constitutionality of the age limit, the court directed itself as follows:

"A Decision may be declared unconstitutional for various reasons including:

(i) Being contrary to the letter and spirit of the Constitution;

(ii) Being in violation of a principle, right or freedom provided in the Constitution;

(iii) Being irrational or disproportionate taking into account the minimum core content of the particular right." 128

The court went on to find that the decision to limit the age of the managing director to 45 years was so restrictive as to be construed as being grossly unreasonable and unconstitutional as it did not conform to the minimum core content of the right to equality and non-discrimination as entrenched in article $27(4)$ of the 2010 Constitution. ${ }^{129}$ The court stated its finding as follows: "[t]he decision was therefore grossly unreasonable as to amount to discrimination

125 Id at 48.

126 [2014] eKIR.

127 Id, paras 7-14.

128 Id, para 62 (emphasis added).

129 Id, para 69. 
on grounds of age contrary to Article 27(4) of the Constitution of Kenya 2010 ... The decision [necessarily] excluded many worthy applicants from being considered on merit to occupy the position of Managing Director of KBC. The decision negated the minimum core content of the right provided under Article 27(4)."130

It would have been more informative of the court in this instance to elaborate on the right to equality and non-discrimination and to state clearly the minimum as well as the more expansive contours of the right. Such an elaboration would have gone a long way towards crystallizing the content of rights and enhancing the understanding of the minimum core approach for the protection of rights in general and socio-economic rights in particular. Despite the failure in this instance, the court's adoption of the minimum core approach signifies that the approach has application in the Kenyan context and can effectively be adopted in the enforcement of the SERs entrenched in the 2010 Constitution.

In relation to SERs, the willingness of the Kenyan courts to listen to a minimum core argument was affirmed in Okwanda $v$ Minister of Health, where the court, decrying a lack of sufficient evidence and argument made by the applicant in a case regarding the right to health and access to medicine, stated:

"On the basis of the material before the court, I find that at least the Government Hospitals provide healthcare to the petitioner at a cost. Whether the form of healthcare provided in these circumstances meets the minimum core obligation or the highest standard is not one that was the subject of evidence and argument before me. The issue of the prohibitive costs involved in accessing the treatment and whether such treatment should be free bearing in mind the necessity to progressively realise these rights was not explored in the depositions and therefore there is no basis upon which $\mathbf{I}$ can make a finding one way or the other."131

It is clear from this pronouncement that, if sufficient evidence and cogent arguments are made in relation to the minimum core approach in the adjudication of SER cases, the courts will be willing to listen to and adopt the approach. The work, therefore, is for litigators to bring before the courts cogent arguments and sufficient evidence so that the courts can be moved to embrace the minimum core approach, as litigation in Kenya is adversarial and the courts are reluctant to adopt new approaches for the enforcement of rights of their own volition.

130 Id, paras 72-73.

131 Mathew Okwanda v Minister of Health and Medical Services and 3 Others [2013] eKLR, para 21. 


\section{THE MINIMUM CORE APPROACH IN COMPARATIVE NATIONAL JURISDICTIONS: SOUTH AFRICA AND COLOMBIA}

\section{A challenge to the minimum core approach in South Africa}

The minimum core approach has, however, not received universal acclaim and has faced its fair share of criticism. One of the staunchest critics of the approach is the SACC which has persistently refused to adopt the approach in several SER cases that it has adjudicated. ${ }^{132}$ Some of the reasons for the court's refusal are as follows.

First, the court held that, due to the different contextual situation of individuals as well as their diverse and varying socio-economic needs, it is difficult to define the minimum core content. ${ }^{133}$ Secondly, the court held that it did not have the information or experience required to be able comprehensively to determine the minimum core content of rights, given the diversity of needs and circumstances of different groups; this differed from the position of the CESCR which had extensive access to, and experience in scrutinizing, several state reports under the ICESCR to enable it to define the minimum core content of rights. ${ }^{134}$ Thirdly, the court stated that the textual construction of the relevant provisions of the South African Constitution did not support the adoption of the minimum core approach, as sections 26(1) and 27(1) did not give an independent and self-supporting positive right, but must be read in relation to sections $26(2)$ and $27(2)$ which in effect limit or qualify the content of the rights to the standards of progressive realisation, resource availability as well as the reasonableness of government measures aimed at their realisation. ${ }^{135}$ Fourthly, the court argued that it was not pragmatic to read the

132 For example: Grootboom; Minister of Health $v$ Treatment Action Campaign 2002 (5) SA 721 (CC) (TAC); and Mazibuko and Others $v$ City of Johannesburg and Others (CCT 39/09) 2010 (3) BCLR 239 (CC). See SA Yeshanew "Approaches to the justiciability of economic, social and cultural rights in the jurisprudence of the African Commission on Human and Peoples' Rights: Progress and perspectives" (2011) 11 African Human Rights Law Joumal 317 at 322.

133 Grootboom, paras 32-33.

134 Id, para 31.

135 Soobramoney $v$ Minister of Health, KwaZulu-Natal 1998 (1) SA 765 (CC), para 24; Grootboom, para 95; TAC, para 32. The limiting of rights in this manner has been extensively criticized by several authors who argue that, even though these standards should of necessity limit the obligations of the state, they should not limit the meaning, nature, content and scope of SERs. See K McLean "Housing" in S Woolman et al (eds) Constitutional Law of South Africa vol 4 (2nd ed, 2006, Juta) 55-1, at 55-9 - 55-12; Bilchitz "Health", above at note 62 at 56A-9 - 10, especially note 4. Bilchitz especially argues passionately for an independent determination of the content of rights, separate from the determination of the obligations of the state, which he avers are the ones limited by the availability of resources. He argues convincingly that the rationale for recognising fundamental rights is the need to protect inherent basic human interests, which people have by virtue of their human characteristics and not by virtue of the resources at their command. He avers that the available resources only affect the capacity of people to realise these inherent rights, and not the rights themselves. He thus contends that an understanding of the 
minimum core content into the SER provisions as this would impose unrealistic demands on the state due to the impossibility of giving everyone "access even to a 'core' service immediately" ${ }^{136}$ Finally, the court acknowledged its institutional incompetence to undertake the formulation of the minimum core content of rights, holding that "courts are not institutionally equipped to make the wide-ranging factual and political inquiries necessary for determining the minimum core standards". ${ }^{137}$ Despite these reasons, the court did not completely reject ever elaborating the minimum core of SERs, holding that the minimum core might be used to determine the reasonableness of a state measure for the realisation of SERs in particular instances. ${ }^{138}$

David Bilchitz, one of the staunchest critics of the SACC's refusal to adopt the minimum core approach, has responded extensively to the criticism of the minimum core approach provided above. He contends that the approach is aimed at protecting the fundamental interests of individuals as well as prioritizing and ameliorating the plight of the worse off, whose needs are not adequately met by a reasonableness standard that fails to recognize the equal importance of each person in society. ${ }^{139} \mathrm{He}$ thus states that, taking into account the weighted prioritization he advocates, the minimum core is a flexible standard which takes into account the needs of the differently situated individuals and groups in society, and is thus not rigid and absolutist. ${ }^{140}$

As has been pointed out by several authors, even though the court in Grootboom did not expressly take up the minimum core arguments made by the amici curiae [friends of the court] in that case, the inclusion of the

contd

content of rights separate from the issue of resources, the approach which he advocates, makes it possible to expect the state to take measures to realise rights which are already present as soon as the problem of scarcity of resources is lessened: see Bilchitz Poverty and Fundamental Rights, above at note 39 at 40-42 and 215-20. See K McLean Constitutional Deference, Courts and Socio-Economic Rights in South Africa (2009) at 176-81 for similar arguments. McLean provides at (179-81) four reasons for adopting her preferred reading; the two critical ones are: first, that the jurisprudential soundness of having a right not restricted by the availability of resources enables the court to align its interpretation of the scope of SERs in accordance with international and comparative norms, and further requires the state to justify failures to realise SERs; and secondly, that it allows for a "wider socio-political understanding of rights as political or ethical claims against the State which stand, even where the State is not able to realise these rights fully".

136 TAC, para 35.

137 Id, paras 37-38.

138 Grootboom, para 33; TAC, para 34. See also Liebenberg Socio-Economic Rights Adjudication, above at note 65 at 148-51 for a similar analysis.

139 Bilchitz Poverty and Fundamental Rights, above at note 39 at 208-13. At 212, however, he rejects lexical prioritization (the requirement that the minimum core must be fulfilled for all before maximal needs are attended to) and instead advocates weighted priorities, which require that, in instances where the minimum core cannot be fulfilled, the state must provide justifications for such failure, and that such justifications must be subjected to stringent scrutiny by the courts.

140 Id at 213. 
requirement that state programmes must be responsive to the urgent needs of those in desperate situations espoused the idea, and the threshold, of the minimum core approach. ${ }^{141}$ This can be gleaned from the Grootboom judgment, where the court stated that an understanding of reasonableness requires that the Bill of Rights be read as a whole because society values human beings and wants to ensure that people are afforded their basic human needs. ${ }^{142}$ In this context, the court held: "[t]hose whose needs are most urgent and whose ability to enjoy all rights therefore is most in peril, must not be ignored by the measures aimed at achieving the realisation of the right ... [T]he Constitution requires that everyone must be treated with care and concern. If the measures, though statistically successful, fail to respond to the needs of those most desperate, they may not pass the test." 143 The court proceeded to state that human beings must be treated as human beings, failing which the constitution is worth infinitely less than the paper on which it is written. ${ }^{144}$ This link portrays the possibilities of mutuality and interrelatedness of the minimum core and the reasonableness approaches that the SACC prefers when adjudicating SERs. ${ }^{145}$

\section{The espousal of the minimum core approach in Colombia}

The refusal of the SACC to take into account the minimum core approach in the realisation of SERs is, however, not representative of the practice of other national jurisdictions with entrenched SERs in their constitutions. A wholehearted espousal of the minimum core approach in understanding, implementing and enforcing SER obligations can be seen in national practice in

141 See Liebenberg Socio-Economic Rights Adjudication, above at note 65 at 153; C Steinberg "Can reasonableness protect the poor? A review of South Africa's socio-economic rights jurisprudence" (2006) 123 South African Law Joumal 264 at 280; McLean Constitutional Deference, above at note 135 at 182-83; R Dixon "Creating dialogue about socio-economic rights: Strong v weak form judicial review revisited” (2007) 5 Intemational Joumal of Constitutional Law 391 at 416; D Bilchitz "Giving socio-economic rights teeth: The minimum core and its importance” (2002) 118 South African Law Joumal 484 at 498-99; Bilchitz Poverty and Fundamental Rights, above at note 39 at $140-42$. Bilchitz argues (at 144-46) that the Grootboom court would not have reached the decision it did without consideration of some level of minimum core, and undertakes an analysis to prove this point. To support this, he quotes from the Grootboom judgment at para 44 where the court held: "A society must seek to ensure that the basic necessities of life are provided to all if it is to be a society based on human dignity, freedom and equality." He concludes (at 147-49) that, in adopting this reasoning, the court adopted the conception of "dignity as integrity" a conception of dignity which supports the adoption of the minimum core content of SERs.

142 Grootboom, para 44.

143 Ibid.

144 Id, para 83.

145 See Young Constituting Economic and Social Rights, above at note 45 at 84-85, where she affirms that the SACC has chosen to place the minimum core under the general purview of the reasonableness approach and uses it as one of the factors to assess the reasonableness of the state's measures aimed at the realisation of SERs. 
domestic jurisdictions, as espoused by the Constitutional Court in Colombia (CCC), ${ }^{146}$ a country with a similar constitutional clause incorporating international human rights law from ratified treaties into the national jurisdiction as part of national law. ${ }^{147}$ The court's commitment to the minimum core approach has been exemplified by its development of the concept of "the minimum conditions for dignified life" or "the right to a vital minimum", a concept constructed from the principle of the social state as entrenched in the constitution as well as the rights to life, human dignity, health, work and social security. ${ }^{148}$ The right to a vital minimum gave citizens an entitlement to the satisfaction of at least the minimum social needs to enable them to have dignified lives. ${ }^{149}$ The concept of the vital minimum has been key in responding to the socio-economic needs of the poor and vulnerable groups in Colombia, as it has served two important purposes: it determined that SERs in the constitution were sufficiently linked with the other "fundamental" rights in the constitution to the point that they could be enforced via the tutela; ${ }^{150}$ and it established a vision of SERs focussed on groups with the most pressing needs and demanded the prioritization of government resources for the amelioration of these needs. ${ }^{151}$ It thus required the state to prioritize its expenditure towards ensuring that all citizens have access to minimum levels of food, clothing and housing, which affected citizens could move the court to enforce through the tutela.

This approach has been used in individual cases, such as a case on the right to health, in a situation of 22 tutela actions dealing with a systematic violation

146 See id at 196-98, where Young contends that, due to the "social State rule of law" vision of the 1991 Colombian Constitution, the CCC has not understood its role in relation to the separation of powers doctrine, but in terms of a substantive constitutional vision of the normative importance of rights and the special role that the constitution accords judicial officers in enhancing the realisation of rights.

147 Chowdhury "Judicial adherence", above at note 42 at $7-8$, affirms that the CCC has adopted and uses the minimum core approach as expounded by the CESCR. He cites some of the cases dealing with housing and health where the court has categorically applied the minimum core content approach, including: CCC decision, T-859, 2003; CCC decision, T-025, 2004; and CCC decision, T-585, 2006.

148 M Sepulveda "The Constitutional Court's role in addressing social injustice" in M Langford (ed) Social Rights Jurisprudence: Emerging Trends in International and Comparative Law (2009, Cambridge University Press) 144 at 148.

149 D Landau "The promise of a minimum core approach: The Colombian model for judicial review of austerity measures" in A Nolan (ed) Economic and Social Rights after the Global Financial Crisis (2014, Cambridge University Press) 267 at 270.

150 A tutela is an innovative writ of protection of fundamental rights enshrined in art 86 of the Colombian Constitution; it can be filed by any person whose fundamental rights are threatened or violated and requires immediate protection. It entails a summary proceeding with the judge obliged to provide a resolution within ten days of a writ being filed. See Sepulveda "The Constitutional Court's role", above at note 148 at 146.

151 D Landau "The reality of social rights enforcement" (2012) 53 Harvard International Law Journal 401 at 420 . 
of the right to health in Colombia. ${ }^{152}$ The court, adopting the right to health framework expounded by the CESCR in General Comment No 14, restructured the entire Colombian health system by giving content to the right to health. ${ }^{153}$ It distinguished essential minimum core aspects of the right to health, that were immediately enforceable, from those aspects which were subject to progressive realisation taking into account available resources. ${ }^{154}$ The court thus ordered the provision of specific health goods and services, such as the provision of viral load tests, anti-retroviral treatment for HIV/AIDS and costly cancer treatment, the implementation of which were resource intensive. ${ }^{155}$

The espousal of the minimum core content approach by the court can also be seen in an earlier case on the situation of internally displaced persons (IDPs). ${ }^{156}$ One of the three main orders of the court was for the government to guarantee the protection of survival-level content (essential core) of the most basic rights, such as the right to food, education, healthcare, housing and land within a stringent period of six months from the date of the decision. ${ }^{157}$ The adoption of the minimum core in this case led to an improvement in access to education and healthcare for the IDPs, with nearly 80 per cent of them benefitting. ${ }^{158}$ In another case, concerning the validity of article 183 of Law 115 of 1994 that authorized public education institutions to

152 CCC Decision T-760 of 2008, discussed in MA Olaya "The right to health as a fundamental and judicially enforceable right in Colombia" (2009) 10(4) ESR Review at 16-17, available at: <http://reference.sabinet.co.za/webx/access/electronic_journals/esrrev/esrrev_v10_ n4_a6.pdfs (last accessed 13 June 2015); AE Yamin and OP Vera "How Do Courts Set Health Policy? The case of the Colombian Constitutional Court" (17 February 2009) at 1-4, available at: <http://journals.plos.org/plosmedicine/article?id=10.1371/journal. pmed.1000032> (last accessed 13 June 2015).

153 Yamin and Vera argue (id at 3) that, in adopting the health jurisprudence of the CESCR, the court: (i) elaborated on the multiple dimensions of state obligations on the right to health, and the importance of monitoring and oversight to enhance protection and accountability; and (ii) reiterated the state's responsibility to adopt deliberate measures to achieve progressive realisation and the impermissibility of retrogression, as well as the importance of transparency, access to information and public participation in the realisation of the right to health.

154 Id at 3-4; Chowdhury "Judicial adherence", above at note 42 at 8; Olaya "The right to health", above at note 152 at 16-17. Olaya's analysis of the court's minimum core reasoning indicates that the court acknowledged that: the right to health has both positive (which require resources to implement) and negative (which require state abstention) obligations; enforceability of positive obligations (as the vital minimum) depended on their urgency and the impact on human dignity of their non-implementation; and non-implementation of positive obligations which did not have an adverse impact on human dignity was subject to progressive realisation.

155 Yamin and Vera, id at 2.

156 Sentence T-025/04; this judgment was the outcome of the aggregation of 1,150 constitutional complaints (tutelas) by IDPs.

157 C Rodriguez-Garavito "Beyond the courtroom: The impact of judicial activism on socioeconomic rights in Latin America" (2010-11) 89 Texas Law Review 1669 at 1682 and 1693.

158 Id at 1686 . He remarks however (at 1687) that, due to the high number of IDPs, with over 5 million IDPs in the last 25 years and 280,000 IDPs in 2010 alone, access to the other SERs 
implement charges for education, the court, taking into account international human rights law as incorporated in Colombia's domestic jurisdiction through articles 44,67 and 93 of the constitution, ${ }^{159}$ held that a right to free primary education was immediately enforceable. ${ }^{160}$

Manuel Cepeda-Espinoza, a former CCC judge, has defined the Colombian system of protecting rights as "biting substantive progressiveness".161 "Progressiveness" recognizes that: rights are not absolute, and must be developed and expanded within certain limitations; implementation of rights must show advancement accompanied by proof of progress; and advancement should show progressiveness towards the effective enjoyment of rights. ${ }^{162}$ The "substantiveness" of the approach is indicated by two phenomena: the adoption of a fixed standard that substantively defines the scope and content of rights (including the minimum core); and the court's ability to give a remedy to individual petitioners while at the same time ordering structural remedies to cover similarly situated people, a contrast to the South African situation exemplified in Grootboom. ${ }^{163}$ The "biting" nature of the approach is indicated by the extensive nature of the decisions as they impose government expenditure on implementation, order administrative and policy changes, and prompt regulatory action.

Though not a panacea for the realisation of SERs, the exemplary use of international law, the incorporation of minimum core standards in the adjudication of SERs, the definition of the substantive content of SERs and the court's willingness to make substantive orders for the amelioration of the conditions of poor and marginalized groups in society as exemplified by the CCC's jurisprudence, is a good example for Kenyan courts to follow in SER litigation. Adopting such an approach will ensure that the entrenched SERs have a practical impact on the lives of poor and marginalized individuals and groups in Kenya, the section of society that most requires the realisation of SERs.

contd

has been unsatisfactory, with $98 \%$ of IDPs living in poverty and only $5.5 \%$ having adequate housing.

159 See amicus brief to case C-376/10 of 2010, prepared by The Comell International Human Rights Clinic, Robert F Kennedy Centre for Justice and Human Rights, and Association NOMADESC (November 2009) at 1, available at: <http://www.escr-net.org/usr doc/Amicus-Brief-w-Annexes-Report-ENG-FINAL.pdf> (last accessed 6 April 2012).

160 See CCC decision C-376/10, available at: <http://www.escr-net.org/caselaw/caselaw_show. htm?doc_id=1407210> (last accessed 6 April 2012).

161 MJ Cepeda-Espinoza "Transcript: Social and economic rights and the Colombian Constitutional Court" (2010-11) 89 Texas Law Review 1699 at 1702-03.

162 Ibid. Transparent rights-based rationality, which requires the state to define objectives, rationalize means to objectives, develop policies and regulations aimed at the fulfilment of objectives and to build institutional capacity to enhance the achievement of objectives, can also be said to form part of the substantive aspect of the approach.

163 Id at 1703. 


\section{CONCLUSION}

Poverty, inequality and socio-economic marginalization have plagued Kenya for a long time, with Kenya recording high poverty and inequality levels as compared to most states within the African region. These challenges led to the fight for a new constitutional dispensation aimed at enhancing human dignity, ensuring substantive equality and lifting living standards of the Kenyan people. Advocacy for a new constitution culminated in the promulgation of a new constitution in August 2010, which entrenched justiciable SERs as a vehicle for improving the living conditions of the poor, vulnerable and marginalized individuals and groups in the country. The mere entrenchment of these rights into a constitution as paper rights is, however, not sufficient; there is still need for their effective as well as scrupulous implementation to improve the practical socio-economic situation of the target groups.

This article has proposed the adoption of the minimum core approach by both the political and the judicial organs of the state in the realisation of SERs so as to enhance the conditions of the poor, vulnerable and marginalized groups, with the aim of achieving the transformative aspirations of the 2010 Constitution. It has submitted that the direct espousal of international law in the Kenyan domestic legal system as per article 2(5) and (6) of the 2010 Constitution requires that Kenya adopt the minimum core approach in good faith in line with its commitments under international law. The article has further argued that the adoption of the minimum core approach is supported by several provisions of the 2010 Constitution, especially: article 20 (2) that provides for the enjoyment of rights in the constitution to the greatest extent consistent with the nature of the rights; articles 20(3)(b) and 259(1) that call for the adoption of an interpretation that most favours the enforcement of rights; and articles $20(5)(\mathrm{b})$ and $21(3)$ that require the prioritization of the needs of the most marginalized and vulnerable groups in society. It is submitted that the adoption of the minimum core approach as per these constitutional provisions will enhance the realisation of the purpose for which the rights, especially the SERs, were entrenched in the constitution, which, as per article 19(2), is to preserve the dignity of individuals and communities and to promote social justice and the realisation of the potential of all human beings. 